\title{
A FORCED HAND: NATIVES, AFRICANS, AND THE POPULATION OF BRAZIL, 1545-1850*
}

\author{
JUSTIN R. BUCCIFERRO \\ Eastern Washington University ${ }^{\mathrm{a}}$
}

\begin{abstract}
The settlement and expansion of the Portuguese colonies in South America were made possible by slave labour; however, the historical size of enslaved Native and African groups is largely unknown. This investigation compiles extant statistics on the population of «Brazil» by race and state for the pre-census period from 1545 to 1850 , complementing them with headcount estimates based on sugar, gold, and coffee production; pre-contact indigenous populations; and trans-Atlantic slave voyages. The resulting panel of demographic data illustrates national and regional racial transitions encompassing the colonial era. Brazil's population was of Native descent but became predominantly African in the $18^{\text {th }}$ century; people of European ancestry remained a minority for another 200 years.
\end{abstract}

Keywords: Brazil, colonisation, demography, race, slavery

JEL Code: N01, N36, N56, N96, O54

\footnotetext{
* Received 3 September 2012. Accepted 28 May 2013. The author is grateful to Ann Carlos and David Bunting for their comments on earlier versions of this article; two anonymous referees for their suggestions, as well as Antonio Tena (former editor) and William Summerhill (editor); and, Luis Dopico and participants in the «Economics of Ethnicity and Race» session at the 37th Annual Meeting of the Economic and Business Historical Society (Las Vegas, April 2012).

a Department of Economics, 013 Hargreaves Hall, Cheney, WA 99004, USA. jbucciferro@ewu.edu
} 


\section{RESUMEN}

El establecimiento y la expansión de las colonias portuguesas en Sudamérica fueron posibles gracias al trabajo de los esclavos; sin embargo, el tamaño histórico de los grupos nativos y africanos esclavizados es desconocido. Esta investigación compila las estadísticas existentes sobre la población de «Brasil» según raza y estado para el periodo pre-censo 1545-1850, complementándolas con estimaciones basadas en la producción de azúcar, oro, y café; poblaciones indígenas precolombinas; y viajes transatlánticos. El panel resultante de datos demográficos ilustra transiciones raciales nacionales y regionales, a lo largo de la era colonial. La población de Brasil era nativa pero se volvió predominantemente africana durante el siglo XVIII; gente de origen europeo siguió siendo una minoría por otros 200 años.

Palabras Clave: Brasil, colonización, demografía, raza, esclavitud

\section{INTRODUCTION}

For at least 250 years (from the early $16^{\text {th }}$ to the late $18^{\text {th }}$ century), the majority of people in Brazil were coerced labourers or slaves; for about 400 years (until the early $20^{\text {th }}$ century), the majority were "slaves» or their descendants ${ }^{1}$. Brazil is the fifth-largest country in the world by area and population (8.5 million $\mathrm{km}^{2}$ and 205.7 million; CIA 2012) and it received nearly half of all slaves brought to the Americas (5.5 of 12.5 million; TransAtlantic Slave Trade Database (TASTD) 2010). Its economy, institutions, and identity were profoundly influenced by slavery, yet «...there is practically no statistical information for the first 250 years of its existence» (Marcílio 1984, p. 37) and it has the trans-Atlantic trade with the least data coverage (Eltis et al. 1999).

I explore the population history of Brazil from its discovery by Europeans in 1500 until the end of the international slave trade in 1850, focusing on how European technology and New-World resources combined to guide the size, scope and racial composition of their settlements. The demographic history of Brazil has been summarised in global studies (e.g. McEvedy and Jones 1978; Livi-Bacci 1992) and regional (e.g. Rosenblat 1954; Sánchez-Albornoz 1974); the underlying sources, however, indicate that such estimates are

1 I consider "Brazil» as the Portuguese, then independent, domain in the New World where indigenous, African, and European elements combined - its borders expanded from a few settlements to span the modern state. The fraction of the population that was enslaved declined to about one-half during the late $18^{\text {th }}$ century (Alden 1963; Livi-Bacci 2001) and about one-quarter by 1850 (Klein and Luna 2010). Only in the early $20^{\text {th }}$ century did people of European descent replace African as the racial majority (Instituto Brasileiro de Geografia e Estadística). 
rather tentative. Country-level analyses by Marcílio (1984) and Livi-Bacci (2001) confirm that knowledge regarding the size and spatial distribution of Brazil's population during the pre-census era is incomplete.

Forced labour had a prominent role in the historical development of Brazil. Everyday people are familiar with its legacy, yet regional changes in racial composition over time are not well-understood, nor are the economic incentives which caused them. Racial diversity is a positive force, yet it is also associated with low public goods provision and poor institutions (Alesina and La Ferrara 2005). It is therefore important to understand the origins of racial geography in Brazil; in particular, the system of production that prompted the forced migration of millions of African or indigenous peoples.

This investigation is organised into three broad periods, loosely labelled as the "sugar era» $\left(16^{\text {th }}-17^{\text {th }}\right.$ century); the "gold era» $\left(18^{\text {th }}\right.$ century); and the "coffee era» $\left(19^{\text {th }}\right.$ century). For each epoch, I provide consolidated population statistics by state and race, forward projections of the initial Native population, output and workforce estimates, and African slave import figures. These data allow me to reconstruct Brazil's early demographic history through its reliance on coerced labour, showing how slave trade dynamics impelled regional shifts in racial identity.

Similar methods have been used to evaluate national population figures for Brazil (e.g. Simonsen 1937; Goulart 1975), but never in a comprehensive way. I find that the observations of early administrators and chroniclers are credible, often coinciding with alternative estimates, and describe racial trends across states for ten reference periods $(1545,1570,1585,1625,1675$, $1725,1775,1800,1825$ and 1850) before the first national census of 1872 . Declining Native populations and insatiable labour demand prompted the massive importation of African slaves to Brazil, making it an "African» nation by the mid- $18^{\text {th }}$ century.

\section{THE SUGAR ERA}

The section of South America that would become known as Brazil was discovered by the Portuguese in 1500 during their maritime expansion. At the time, they had already settled several Atlantic islands, established trading forts down the African coast, rounded the Cape of Good Hope, and reached the Indian Ocean (Mauro 2000). For roughly thirty years, the Portuguese traded with aboriginals for brazilwood (a dyewood which gave the region its name), but challenges for the region hastened its direct settlement (Souza 2000) ${ }^{2}$.

2 The Portuguese brazilwood trade relied on «factories» like those in Africa; there were few year-round inhabitants and no permanent settlements. The French were also active in the trade and (like the Dutch) contended the region. 


\subsection{European settlement}

The area of South America to the east of the Line of Tordesillas (set by Spain and Portugal in 1494) was divided into fifteen lots and allocated to twelve men with court connections (Johnson 1987). By 1540, only seven «captaincies» were effectively settled - São Vicente, Santos, Itamaracá, Pernambuco, Espírito Santo, Porto Seguro, and Ilhéus - with Bahia and Rio de Janeiro re-established during the following decade (Varnhagen 1956). The original captaincies are illustrated in Figure 1 based on Varnhagen's geographic descriptions ${ }^{3}$.

The impact of colonisation on indigenous societies remains unclear (Cunha 1992). Amerindians were among Portugal's first exports from Brazil, but slavery was limited until the spread of European settlement oriented to agriculture and ranching (Petrone 1995); instead of relying on trade, the agro-pastoral economy became organised upon «the direct appropriation of indigenous labor, above all in the form of slavery» (Monteiro 1994, p. 33).

São Vicente was the starting point for the colonisation of the interior. The region encompassing the city of São Paulo - the Campos de Piratininga was a major pre-historical population centre; from there proceeded expeditions into what would become Mato Grosso, Goiás and Minas Gerais (Petrone 1995). The colonial strategy applied during the $16^{\text {th }}$ century involved the relocation of Natives from their original aldeias (villages) to new ones, proximate to European settlements, administered by the Jesuits. In these aldeamentos, the Jesuits converted Natives and allocated their labour according to the needs of settlers (Perrone-Moisés 1992).

The indigenous population was considered in terms of two broad ethnic groups: the coastal, relatively homogenous Tupi and the interior, more heterogeneous Tapuia (Monteiro 1994). The shock of European contact with its concomitant warfare, disease, enslavement, and displacement created a cascade of social changes with terrible demographic effects. In turn, Monteiro explains, the first major law limiting Native enslavement was enacted in 1570.

The legal status of Brazil's indigenous peoples was ambiguous and often disregarded in practice (Perrone-Moisés 1992; Petrone 1995). In general, one category of legislation applied to Natives in the Jesuit villages (or allies) and another to enemies: the former were technically free but catechised and obliged to work for settlers, the latter could be enslaved (Perrone-Moisés 1992). In effect, Natives within the settlements were uniformly subject to

3 The location of the Line of Tordesillas was not precisely known but thought to cross the mouths of the Amazon and the River Plate (Johnson 1987) - I have shown Ribeiro's 1529 interpretation of $49^{\circ} 30^{\prime} \mathrm{W}$ (in Marchant 1942). Rather than incite the Spanish, the Portuguese monarch delineated the southern captaincies to the north of the River Plate, beginning in Santana at about $28 \frac{1}{3}^{\circ} \mathrm{S}$ (Souza 2000). 
FIGURE 1

CAPTAINCIES AND SETTLEMENTS OF BRAZIL CA. 1545

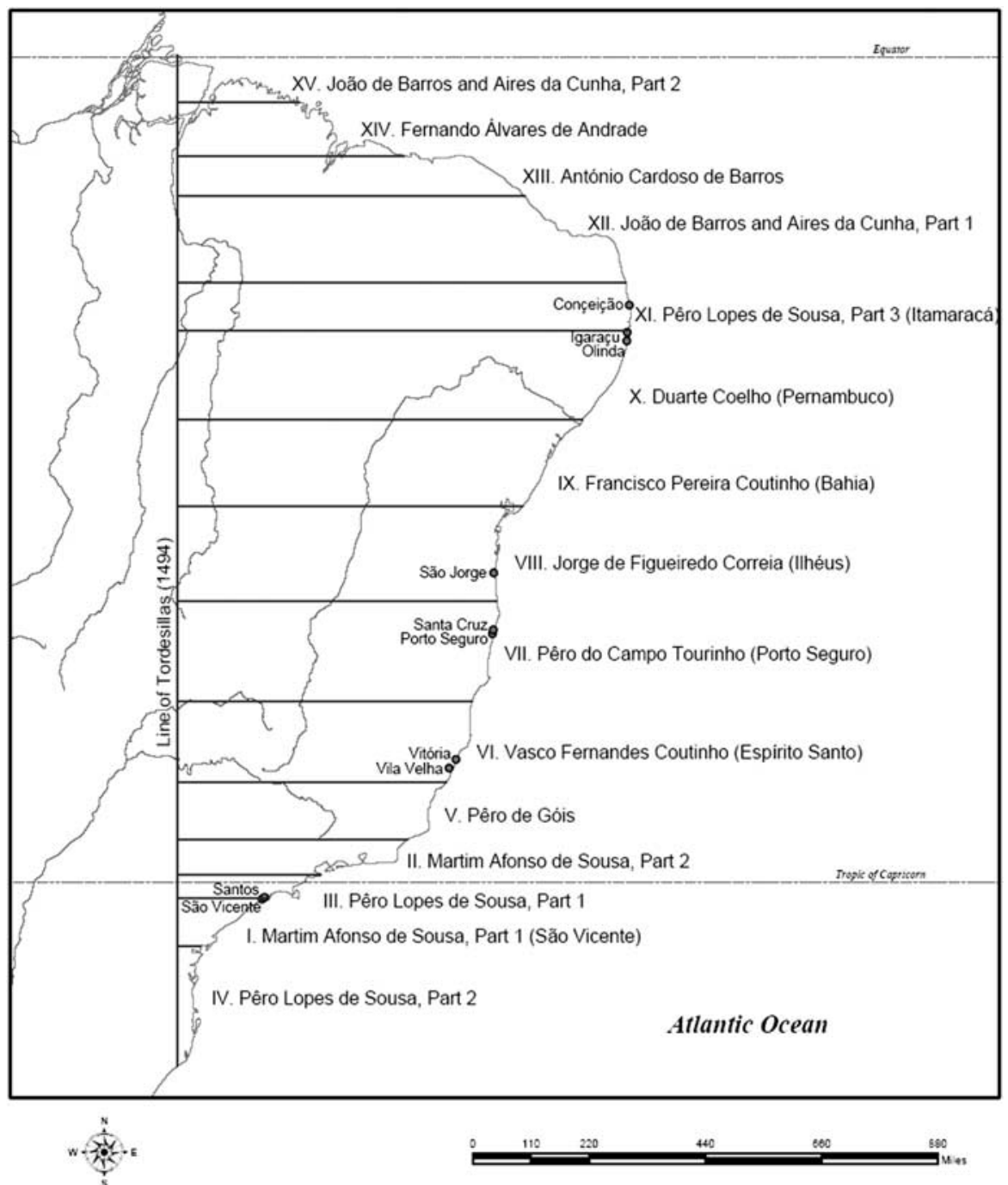

Notes: The 12 «donatory captains» are listed to the right of their respective grants and the names of the captaincies, when applicable, are in parentheses; there are fifteen lots shown, corresponding to fourteen captaincies, and the primary settlements are indicated with their names to the left. 
some form of coercion - ultimately, a necessary factor for the success of the colonial enterprise (Monteiro 1994).

\section{2. $16^{\text {th }}$-century population}

\section{Extant statistics}

Population data for the $16^{\text {th }}$ century are sparse. In 1550 , records suggest at most 3-4,000 European settlers across all captaincies (Marcílio 1984), with about 600 Europeans in São Vicente in 1548 and 300 that settled in Bahia in $1549^{4}$. In São Vicente, there were also 3,000 slaves; other sources cite roughly 400 African slaves in Ilhéus and 500 in São Vicente ca. $1545^{5}$. Gândavo (1965 [1576]) gives numbers of European households in Brazil ca. 1570 which, adopting the convention of six persons per household, suggests that 21,000 Europeans lived there at this time ${ }^{6}$. The Native population overseen by the Jesuits in Bahia, Espírito Santo and São Vicente was a combined 38,000, with 34,000 in Bahia (Marchant 1942). In total, several thousand Africans were employed on the sugar plantations (Marcílio 1984).

For the period ca. 1585, there are three overlapping sources of data: Fernão Cardim (1583), Joseph de Anchieta (1585), and Gabriel Soares de Sousa (1587). Their estimates suggest that the total European population of Brazil was about 30,000. Excluding three captaincies for which no data are available, the Native population in those European areas was nearly 18,000; in just three captaincies with data, the African population was almost 10,000. The population figures, by captaincy and race, for the periods around 1570 and 1585 are shown in Table 1 (the 1545 data are too few to repeat here), ordered from north to south.

The three population categories should not be interpreted literally ${ }^{7}$. Factors specific to each period are considered separately, but each racial category is generally construed as follows: (1) the "Native» population includes all aboriginals within the Portuguese domain, whether subjected to forced labour or incorporated into the society of Europeans; (2) the «European» population includes those specifically from Europe in addition to the free population of mainly European descent; and (3) the «African» population includes natural Africans as well as people of mixed AfricanEuropean/Indian lineage classified as Mulattos by contemporaries.

\footnotetext{
4 Letter of Luís de Góis to the King dated May 12, 1548, Documentos Historicos, XXXVII.

5 Letter of Luís de Góis to the King dated May 12, 1548, Documentos Historicos, XXXVII; As Gavetas da Torre do Tombo, Lisbon, 1962, II, 583; P. Meréa, Historia da Colonia Portuguesa, III, 181.

6 Anchieta (1585) refers to six persons per household; for the $18^{\text {th }}$ century, when the first regional census data are available, the average household size was also roughly six (Alden 1963).

7 Race is a social construct and intermixture over time makes such distinctions ambiguous, it is often classified differently across sources, and one cannot properly consider those born in Brazil as «Africans» or «Europeans».
} 
TABLE 1

THE POPULATION OF «BRAZIL» DURING THE LATE $16^{\mathrm{TH}}$ CENTURY

\begin{tabular}{|l|c|c|c|c|c|c|}
\hline & \multicolumn{4}{|c|}{1570} & \multicolumn{3}{c|}{ 1585 $^{3}$} \\
\hline Captaincy & Native $^{\mathbf{1}}$ & European $^{\mathbf{2}}$ & African & Native & European & African \\
\hline Itamaracá & - & 600 & - & - & 300 & - \\
\hline Pernambuco & - & 6,000 & - & 2,000 & $6,660-14,100$ & $2-10,000$ \\
\hline Bahia & 34,000 & 6,600 & - & $6-8,000$ & $12-18,000$ & $3-4,000$ \\
\hline Ilhéus & - & 1,200 & - & - & $300-900$ & 500 \\
\hline Porto Seguro & - & 1,320 & - & - & $480-600$ & - \\
\hline Espírito Santo & $1,500-3,000$ & 1,200 & - & 4,500 & 900 & - \\
\hline Rio de Janeiro & - & 840 & - & 3,000 & 900 & - \\
\hline São Vicente & 1,000 & 3,000 & - & 1,000 & $1,800-1980$ & - \\
\hline Total & $>38,000$ & 20,760 & - & $>16,500-18,500$ & $23,340-37,680$ & $>5,500-14,500$ \\
\hline
\end{tabular}

Sources: ${ }^{1}$ Marchant (1942), based on parish registers in the Cartas Avulsas and the writings of Joseph de Anchieta.

${ }^{2}$ Gândavo, Tratado da Provincia do Brazil (1576), based on six persons per household.

${ }^{3}$ Range of Anchieta (Cartas, Informações, Fragmentos Historicos e Sermões, 1585), Cardim (Narrativa Epístolar de uma Viagem e Missão Jesuítica, 1583), and Soares de Sousa (Tratado Descritivo do Brasil, 1587).

Around 1545, indigenous peoples outnumbered Europeans and Africans (there may have been as many Natives in São Vicente alone as Europeans across all eight captaincies). Table 1 shows that the majority was still indigenous in 1570, even though the São Vicente figure appears low. There were probably several thousand Africans at this time and by 1585, perhaps 15,000. A smallpox epidemic devastated the Native population of Bahia during the 1560s and 1570s (Marchant 1942), potentially making Europeans a (brief) majority in the settlements as of 1585 .

\section{Production-based estimates}

Limited data from colonial records on Native and African populations can be supplemented by estimates based on the output of sugar. The productivity of the existing technology, combined with information on the number of engenhos (sugar mills or plantations), provides an estimate of the number of workers. I briefly describe the production process and present data on the number of plantations and projected workforce.

Harvestable sugarcane takes fifteen to eighteen months to grow, with a second harvest possible after another nine months; the cane is cut by gangs and the juice is expressed, after which it is boiled, purged, and dried in pots to create sugar (Schwartz 1987). A large plantation may have employed from 120 to 160 slaves in the field, forty slaves during the milling process, and 
twenty Europeans (Blume 1985). Contemporary sources indicate that the average $16^{\text {th }}$-century plantation employed about eighty slaves and produced 3,000 arrobas (43 tonnes) of sugar per year ${ }^{8}$.

Even if sufficient free workers had been available (at the time Portugal's low population did not encourage emigration), slaves would still have been preferred: they were more reliable because of their lack of freedom; more efficient because they could be overworked during key times in the agricultural cycle; and no more costly than free labourers (Bergad 2007). Between 1870 and 1881, Carvalho de Mello (1977) estimates that the threeyear average return on prime male field slaves in the coffee sector ranged from 11.5 per cent to 15 per cent, at least as great as that of other capital assets. The average rate of return on investment in slaves was relatively high, and the purchase price of a slave could be recovered in a few years (Slenes 1975; Schwartz 1985).

The extent to which the number of slaves on the sugar plantations corresponds to the overall African or Native population depends on the relative importance of sugar in the economy. It was the major product during the $16^{\text {th }}$ and $17^{\text {th }}$ centuries, comprising over 70 per cent of output (Goulart 1975). The settlements were chiefly oriented towards sugar production - the number of plantations and extant technologies suggest the size of the enslaved population (but may underestimate it, depending on the prevalence of slaves in other sectors).

Data on the number of sugar plantations in each captaincy for the period ca. 1545 come from contemporary documents cited by Johnson (1987); and for the periods ca. 1570 and 1585, from Gândavo (1576), Soares de Sousa (1587), Cardim (1583) and Anchieta (1585). Based on these and other sources (see footnote 8 ), I assume that there were eighty slaves per plantation - the average number recorded by contemporaries, which corresponds to a medium-sized plantation. The number of plantations and associated slave labour force are presented in Table 2.

Sugar production became concentrated in the captaincies of Pernambuco and Bahia, where 8,960 slaves may have laboured in 1585. To the south, in Porto Seguro and Espírito Santo, there was ongoing warfare with the Aimoré and some villages, with their plantations, were destroyed (Varnhagen 1956).

\footnotetext{
8 Abreu de Brito (1592) suggests annual production per sugar plantation of 6,000 arrobas, an estimate repeated by Blume (1985); Gândavo (1576) and Cardim (1583) claimed 3,000, repeated by Klein and Luna (2010). Average production was $<6,000$ arrobas, the figure for a large plantation, and productivity was lower further back in time. Three thousand arrobas per plantation is consistent with Schwartz (1985), who reports an average 2-5,000 for the $17^{\text {th }}$ century, when productivity was higher. Blume suggests over 120 slaves worked on a typical plantation. Cardoso (1983) recommends 80 as a fair, but high estimate. Goulart (1975) cites De Laet (1644), who argues that large engenhos had about 100 African slaves, and Van de Dussen (1640), who proposes a standing workforce of forty to seventy slaves for as many arrobas produced. The range of estimates is from forty to 120 slaves per plantation with an average of about eighty - a number typical of Spanish America during the following century (Schwartz 1985).
} 
TABLE 2

SUGAR PLANTATIONS AND $16^{\mathrm{TH}}$ CENTURY SLAVE WORKFORCE

\begin{tabular}{|l|c|c|c|c|c|c|}
\hline & \multicolumn{2}{|c|}{$\mathbf{1 5 4 5}^{\mathbf{1}}$} & \multicolumn{2}{c|}{$\mathbf{1 5 7 0}^{\mathbf{2}}$} & \multicolumn{2}{c|}{$\mathbf{1 5 8 5}^{\mathbf{3}}$} \\
\hline Captaincy & \# Engenhos & Workforce & \# Engenhos & Workforce & \# Engenhos & Workforce \\
\hline Itamaracá & - & - & 3 & 240 & $6^{4}$ & 480 \\
\hline Pernambuco & 5 & 400 & 23 & 1,840 & 66 & 5,280 \\
\hline Bahia & 2 & 160 & 18 & 1,440 & 46 & 3,680 \\
\hline Ilhéus & $-*$ & $\sim 160$ & 8 & 640 & 6 & 480 \\
\hline Porto Seguro & - & - & 5 & 400 & $1^{5}$ & 80 \\
\hline Espírito Santo & 4 & 320 & 1 & 80 & 6 & 480 \\
\hline Rio de Janeiro & - & - & 0 & 0 & 3 & 240 \\
\hline São Vicente & 6 & 480 & 4 & 320 & 4 & 320 \\
\hline Total & 17 & 1,520 & 62 & 4,960 & 138 & 11,040 \\
\hline
\end{tabular}

Sources: ${ }^{1}$ Johnson (1987, pp. 31-34).

${ }^{2}$ Gândavo, Tratado da Província do Brasil (1576).

${ }^{3}$ Anchieta, Informação da Província do Brasil para nosso Padre (1585).

${ }^{4}$ Soares de Sousa, Tratado Descritivo do Brasil em (1587).

${ }^{5}$ Cardim, Narrativa Epístolar de uma Viagem e Missão Jesuítica (1583).

Notes: "Ilhéus did produce sugar at this time; the number of plantations is unknown, but was likely from two to four (Varnhagen 1956).

Slave imports provide another way of checking the reliability of the African population figures cited by contemporaries.

According to Goulart (1975): African slaves were first imported to Brazil between 1516 and 1526 by Pero Capico or Martim Afonso, who were among the first to establish sugar plantations. There were petitions for slaves during the 1540s and 1550s, yet few references to Africans actually in Brazil ${ }^{9}$. In 1559 , each plantation owner was allowed to import up to 120 "Congo» slaves - registers of only four such shipments are in the TASTD. The letter of Domingos d'Abreu de Brito to Felipe II reports that 52,053 slave "pieces» left Angola for Brazil from 1575 to 1591; of these, only a fraction were probably destined for the Portuguese colonies ${ }^{10}$.

There were 138 sugar plantations ca. 1585 , so over 16,000 African slaves could have been imported, a figure Goulart (1975) reaches based

9 Duarte Coelho and Pêro de Goís solicited over sixty slaves each in 1545; Nobrega petitioned slaves for the Jesuit school in Bahia in 1551; only Gaspar da Madre de Deus explicitly refers to Africans on the plantations (ca. 1545).

10 A «peça» corresponds to a standard of account - a prime male slave - and the actual number of slaves would exceed the number of peças. Most of these slaves were destined for Spanish America where tariffs were higher. 
on $\sim 80,000$ slaves shipped from Angola, with one-fifth destined for Brazil. The pace of imports would not have declined during the 1590s because sugar production was expanding (Schwartz 1985). The volume of the African slave trade to Brazil was likely under 1,000 before 1545; 2,000 between 1545 and 1570; and at least 16,000 from 1570 to 1590 , with another 10,000 during the following decade. In all, about 30,000 African slaves were brought to Brazil during the $16^{\text {th }}$ century - a figure consistent with 32,000 from TASTD, but below the 50,000 adopted by Curtin (1969) and Eltis (2001).

\section{Projections}

The production and slave-import figures suggest the number of slaves in the colonies; however, it is unclear how many aboriginals were living in the settlements at this time. The pre-contact population of what is today Brazil may have been from one (Rosenblat 1954) to over five million (Denevan 1976; in Newson 2006). Steward (1946) — who combines data on population densities of existing un-acculturated groups and applies these to similar once-occupied areas - arrives at a figure of 1.7 million, revised to 2.5 million by Hemming (1978). For the South American low-lands, Cunha (1992) cites these and other authors (including Sapper 1924; Kroeber 1939; Dobyns 1966) in proposing a range of from 1 to 8.5 million inhabitants.

I base my projections upon Steward's map of indigenous population densities (per $100 \mathrm{~km}^{2}$ ). Although his figures are conservative, they are close to Hemming's (except for areas settled later in the colonial period) and include spatial information. I digitise Steward's map and transform it to obtain the density per square-kilometer. I consider the Portuguese domain as described by Hemming (1978), who shows the frontier as it existed in 1600, 1700 and 1760 , assuming that the frontier expanded linearly ${ }^{11}$. I overlay and intersect three maps - the initial population, areas settled by Europeans over time, and state borders - and export the Native headcounts ${ }^{12}$.

The initial Native population and that population decades or centuries later depends on many factors, including its natural rate of growth, any transitory shocks and inward or outward migration. Ethnographic and archaeological evidence present somewhat conflictive accounts of indigenous prehistory (Roosevelt 1992); unfortunately, only fragmentary evidence is available on the upheavals caused in indigenous societies following the arrival of Europeans.

In his study of the Americas, Rosenblat (1954) concludes that by 1570 Brazil's Native population was only 80 per cent of its size in 1492; 70 per cent

11 I begin with no Portuguese territories in 1500 and end at Brazil's political boundaries as of 2000.

12 The twenty state borders do not coincide with the captaincies, so I aggregate upwards and make adjustments. 
by $1650 ; 36$ per cent by 1825; 20 per cent by 1940; and 20 per cent by 1950 . This corresponds to an average annual population growth rate of -0.37 per cent. Rather than speculate on the extent of population shocks or migration, I adopt this rate of decline and project the Native population of settled areas in each state-year using the pre-contact population data above, producing figures that are surprisingly close to those recorded by contemporaries.

\section{Discussion and consolidated figures}

How do coerced-workforce estimates from sugar production, African slave imports and the initial Native population compare with the accounts of early observers? In 1545, between Bahia and Ilhéus there were from four to six plantations, likely operating with 320 to 480 slaves - the one contemporary figure of 400 African slaves for Ilhéus falls in the middle of this range. In São Vicente, there were six engenhos and potentially 480 slaves - the estimated African population of 500 is also feasible. The total number of slaves required to work the seventeen plantations ca. 1545 was 1,520 compared with the 1,000 supposedly imported by that time. The plantation labour force was mainly African. For the Native population, the contemporary indication of 2,500-3,000 in São Vicente compares to my rounded projection of 2,100.

There are no statistics for the African population of 1570, but Marcílio (1984) holds that there were a few thousand Africans in the captaincies. As there were sixty-two plantations, there must have been around 5,000 slaves; the evidence on slave imports suggests that no more than 2,000 Africans lived in the settlements. A range of 2-5,000 African slaves in Brazil ca. 1570 is most likely. Anchieta's records of the Native population were 34,000 in Bahia, 1,000 in São Vicente, and 1,500-3,000 in Espírito Santo, compared with my projections of 7,800, 3,000 and 800 .

Based on Cardim, Anchieta and Soares de Sousa, anywhere from 2 to 10,000 Africans (5,665 average) were in Pernambuco and 3-4,000 in Bahia (3,665 average) by 1585; an alternate source cites 500 African slaves in Ilhéus. Given the extent of sugar production in these captaincies, roughly 5,280 slaves were needed in Pernambuco, 3,680 in Bahia, and 480 in Ilhéus. The Native population accounted for by the Jesuits compares to my projections, respectively: in Pernambuco - 2,000 vs. 7,800; in Bahia - 6/8,000 vs. 8,900; in Espírito Santo - 4,500 vs. 900; in Rio de Janeiro - 3,000 vs. 1,200; and, in São Vicente - 1,000 vs. 3,400.

The plantation-based estimates are consistent with chroniclers' observations and constitute our best knowledge of the distribution of African slaves across captaincies when demographic data are lacking. The Native projections capture spatial and temporal trends in population size which, although they vary widely, on-average coincide with the Jesuits' records. In Table 3, I consolidate the above data, taking the observed figures when available and adding in the workforce estimates of the African, and projections of the Native, population. 
TABLE 3

CONSOLIDATED POPULATION OF «BRAZIL» BY RACE AND CAPTAINCY (CA. 1545, 1570 AND 1585)

\begin{tabular}{|l|c|c|c|r|r|r|r|r|r|}
\hline & \multicolumn{3}{|c|}{1545} & \multicolumn{3}{c|}{1570} & \multicolumn{3}{c|}{1585} \\
\hline Captaincy & Native $^{\mathbf{3}}$ & European & African $^{\mathbf{2}}$ & Native $^{\mathbf{1}}$ & European $^{\mathbf{1}}$ & African $^{\mathbf{2}}$ & Native $^{\mathbf{1}}$ & European $^{\mathbf{1}}$ & African $^{\mathbf{2}}$ \\
\hline Itamaracá & 4,700 & - & - & $6,600^{3}$ & 600 & 240 & $7,600^{3}$ & 300 & 480 \\
\hline Pernambuco & 4,800 & - & 400 & $6,700^{3}$ & 6,000 & 1,840 & 2,000 & 10,920 & $5,665^{1}$ \\
\hline Bahia & 5,500 & $300^{1}$ & 160 & 34,000 & 6,600 & 1,440 & 7,335 & 14,010 & $3,665^{1}$ \\
\hline Ilhéus & - & - & $400^{1}$ & - & 1,200 & 640 & - & 600 & $500^{1}$ \\
\hline Porto Seguro & - & - & - & - & 1,320 & 400 & - & 540 & 80 \\
\hline Espírito Santo & 500 & - & 320 & 1,500 & 1,200 & 80 & 4,500 & 900 & 480 \\
\hline Rio de Janeiro & 700 & - & - & $1,000^{3}$ & 840 & 0 & 3,000 & 900 & 240 \\
\hline São Vicente & $2,500^{1}$ & $600^{1}$ & $500^{1}$ & 1,000 & 3,000 & 320 & 1,000 & 1,890 & 320 \\
\hline Total & 18,700 & $3,000^{4}$ & 1,780 & 50,800 & 20,760 & 4,960 & 25,435 & 30,060 & 11,430 \\
\hline
\end{tabular}

Sources: ${ }^{1}$ Figures from $16^{\text {th }}$-century documents, averaged when multiple sources available.

${ }^{2}$ Estimated African population based on the number of sugar plantations.

${ }^{3}$ Projected Native headcount from initial population, areas settled and annual growth rate of $-0.37 \%$.

${ }^{4}$ Marcílio (1984). 
Table 3 presents a more-complete account of Brazil's earliest populations. This is particularly so for 1545 , when there may have been 18,700 Natives living in the settlements whereas only a few thousand are cited in contemporary documents. In 1545 and 1570, the settlements' Native population greatly outnumbered the European; however, the European may have eclipsed the Native, albeit temporarily, in 1585 . The African slave population increased at average annual rates of 4 per cent and 6 per cent, more than doubling in-between periods.

\section{3. $\quad 17^{\text {th }}$-century population}

\section{Extant statistics}

During the $17^{\text {th }}$ century, the Portuguese battled the Dutch and French: they united their possessions in Itamaracá and Paraíba and settled the northern captaincies of Maranhão and Pará but lost control of Pernambuco for over two decades (Marcílio 1984). The Native governance system broke down as colonists intensified their slave raiding in the interior (Monteiro 1994); once in the tens of thousands, the Jesuit villages suffered a sangria demográfica (Petrone 1995, p. 243). Due to the unavailability of data, I centre my analysis on two periods - 1625 and 1675 - for which modest coverage is available, using the same methods as for the $16^{\text {th }}$ century.

Contemporary sources describe the European population for most captaincies around 1625. The primary reference is Freyre (1675), whose observations span the period from 1624 to 1638; observations for Ilhéus and Porto Seguro are from Moreno (1612); and, figures for Pará and São Paulo are from Schwartz (1987) and Hemming (1987). Together, these data suggest that there were over 98,000 Europeans across eleven captaincies in 1625. Schwartz claims that there were also 40,000 Natives across the plantations in São Paulo (São Vicente); others describe as many being evangelised in the north. No figures are available for the African population.

For 1675, de Mongelos describes the European and Native population of São Vicente (in Metcalf 1992). Perreira de Berredo (1718) and Viera (1660) describe those of Pará and Maranhão (see Boxer 1962; Hemming 1978; Schwartz 1987); as do Heriarte (1662) and Souto-Maior (1658), in Varnhagen (1956), and the Jesuit documents compiled by Leite (1938). The combined statistics for the $17^{\text {th }}$ century from these sources are presented in Table 4.

The European population rose noticeably by 1625 , and thousands of Natives were incorporated into settlements in Pará-Maranhão and São Vicente; however, demographic data are very limited for both periods because of the ongoing war. I again use the numbers of sugar plantations and corresponding workforces to both evaluate and complement this information. 
TABLE 4

THE POPULATION OF «BRAZIL» DURING THE $17^{\text {TH }}$ CENTURY

\begin{tabular}{|l|c|c|c|c|c|c|}
\hline & \multicolumn{5}{|c|}{$\mathbf{1 6 2 5}^{\mathbf{1}}$} & \multicolumn{3}{c|}{$\mathbf{1 6 7 5}^{\mathbf{2}}$} \\
\hline Captaincy & Native & European & African & Native & European & African \\
\hline Pará & - & 200 & - & 25,000 & 500 & 100 \\
\hline Maranhão & 40,000 & 1,500 & - & 25,000 & 1,000 & 100 \\
\hline Rio Grande & - & - & - & - & - & - \\
\hline Paraíba & - & 4,980 & - & - & - & - \\
\hline Pernambuco & - & 66,000 & 5,000 & - & - & - \\
\hline Sergipe & - & 2,400 & - & - & - & - \\
\hline Bahia & - & 18,350 & - & - & - & 25,000 \\
\hline Espírito Santo & - & 2,400 & - & - & - & - \\
\hline Rio de Janeiro & - & - & - & - & - & - \\
\hline São Vicente & 40,000 & 2,000 & - & 20,050 & 8,900 & - \\
\hline Total & - & $>97,830$ & - & - & - & - \\
\hline
\end{tabular}

Sources: ${ }^{1}$ European population is from Freyre (1675), História da Guerra Brasílica, based on six persons per household; figures for Pará and São Vicente are from Schwartz (1987) and Hemming (1987); those for Ilhéus and Porto Seguro are from Moreno (1612), Livro que Dá Rezão do Estado do Brasil.

${ }^{2}$ Data for São Vicente are from de Mongelos (in Metcalf, 1992); for Pára, Maranhão, and Bahia from Anais Historicos (Perreira de Berredo), Regulamento das Aldeias (Viera) and Suma Histórica (Leite).

\section{Production-based estimates}

Although the average number of slaves employed on each engenho, or plantation, does not appear to have changed from the previous century, the technology did: the three-roller vertical mill caused an expansion in the output of sugar (Schwartz 1985). Based on available figures for the early $17^{\text {th }}$ century, average sugar production per plantation increased to about 4,000 arrobas (57 tonnes) a year, a one-third rise in worker productivity ${ }^{13}$.

There are two sources of information on the number of plantations operating in Brazil ca. 1625: Cadena (1629) and Freyre (1675). Cadena gives a total of 245 engenhos and Freyre, 346; however, Cadena omits Rio de Janeiro (which had 60+ plantations) making both sets of figures comparable.

13 By 1644, medium engenhos in the Dutch possessions were said to produce 4-5,000 arrobas a year, with large ones producing 7-8,000 arrobas and smaller ones under 3,000 (de Laet 1644; in Goulart 1975). Based on data from Schwartz (who cites Monteiro, da Costa and Cadena) and de Laet's testimony, the average sugar output per engenho was above 3,000 arrobas but no more than 4,500 arrobas achieved in Pernambuco and Bahia. 
TABLE 5

SUGAR PLANTATIONS AND SLAVE WORKFORCE CA. 1625

\begin{tabular}{|l|c|c|}
\hline Captaincy & \# Engenhos & Workforce* \\
\hline Rio Grande & 2 & 160 \\
\hline Paraíba & 22 & 1,760 \\
\hline Itamaracá & 21 & 1,640 \\
\hline Pernambuco & 8 & 10,840 \\
\hline Sergipe & 75 & 640 \\
\hline Bahia & 3 & 5,960 \\
\hline Ilhéus & 8 & 240 \\
\hline Espírito Santo & 60 & 640 \\
\hline Rio de Janeiro & 2 & 4,800 \\
\hline São Vicente & 336 & 160 \\
\hline Total & & 26,840 \\
\hline
\end{tabular}

Sources: The number of plantations is the average of Cadena (1629), Descripción de la Provincia del Brasil, and Freyre (1675), História da Guerra Brasílica.

Notes: *The workforce is based on an average of 80 slaves per plantation.

There are no other reports until 1711: Antonil's Cultura e Opulência do Brasil indicates 528 plantations across Pernambuco, Bahia and Rio de Janeiro alone. It is possible that there were around 450 in Brazil ca. 1675, but it is difficult to discern. Table 5 presents the average numbers of plantations of Cadena and Freyre and resultant slave workforces.

\section{Projections}

The volume of slaves brought from Africa to Brazil increased manifold during the $17^{\text {th }}$ century, but documentation has survived for few voyages ${ }^{14}$. Although the TASTD provides its own annual estimates of African slave imports based on inferred data coverage, I take an uninformed approach and create new time-series estimates of annual imports using only recorded voyages and their purported cargoes. This ignores useful contextual information on the completeness of bookkeeping over time but involves fewer assumptions.

I apply an exponential smoothing mechanism to the annual slave import totals across the voyages logged in TASTD, which provides figures for one-half of the years from 1574 to 1856 . The sum of the resulting annual slave import estimates is below the volume believed to have arrived in Brazil

14 The TASTD includes 146 voyages across 37 years, about 35,000 total slaves. 
(2.14 vs. 3.5-5.5 million); however, the recorded volume was probably only half the total trade (Goulart 1975), a scenario consistent with the consensus of four million. To benchmark the African population, I assume that half of slave voyages were documented.

With data on the annual flow of slaves into the settlements, I calculate a reference African headcount for each period based on hypothesised natural rates of population growth. Slave mortality was not constant over the course of the traffic; neither was the share of the Afro-Brazilian population that was enslaved. Free peoples had a longer life expectancy because of high mortality among newly arrived slaves and the abuses of forced labour; they also experienced higher rates of natural growth because the population's age-sex structure was more balanced.

Slaves' lives were «unnaturally short», writes Conrad (1986). Contemporary estimates of the working life of a slave in the mines range from seven to twelve years (Russell-Wood 1987), and the mortality rate on a sugarcane plantation was estimated by planters at 5-10 per cent annually (Schwartz 1987). Conrad cites a British report from 1843 that states that, in the best case, mortality in the first year of arrival was at least 8 per cent, and 6 per cent the following year.

Carvalho de Mello (1977) describes the estimates of contemporaries as unreliable, however, and uses the 1872 national census data for free and slave, African and Mulatto, to estimate upper and lower bounds for the life expectancy of slaves. Specifically, he employs the population age distribution (stable population theory) and adjusts for the influence of imports to arrive at an estimated life expectancy at birth of eighteen to twenty-three years for a male slave. This roughly corresponds to a crude death rate of between 4 per cent and 6 per cent a year.

A major impediment to the ability of the slave population to maintain itself was the high male-to-female ratio and correspondingly low number of births. Merrick and Graham (1979) report that in Minas Gerais in 1786, the male-to-female ratio among "Africans» (negros) was 2.25 to 1 but among Mulattos (pardos), many of whom were free, it was just 0.94 to 1 . In the decades since their work was published, a host of new evidence has emerged which clarifies regional trends in the age-and-sex distribution of Brazil's free and slave populations.

Luna (1980) describes the slave demographics of some localities in Minas Gerais for separate periods between 1718 and 1804: in Vila de Pitangui, the average male-to-female ratio between 1718 and 1723 was 5.4 to 1; in Serro do Frio in 1738, it was 5.1 to 1; in Freguesia de Congonhas do Sabará in 1771, it was 2.7 to 1; and in Distrito de S. Caetano and Vila Rica, the average was just 1.4 to 1 in 1804. Each region was not uniform, but such differences do not arise from spatial heterogeneity alone: note how the share of native-born slaves ranged from 16.7 per cent in Pitangui between 1718 and 1723 to 59.4 per cent across S. Caetano and Vila Rica in 1804. 
Other studies include Libby and Paiva (2000), which employs ecclesiastical records of the Freguesia de São Jose to trace the characteristics of slave, free and manumitted groups in 1795 Minas Gerais. Native-born slaves were found to have a wide-based and symmetrical population pyramid, indicating a balanced sex ratio and natural reproduction. With unpublished censuses for Minas Gerais and São Paulo ca. 1830, Klein and Luna (2004) also reveal that the mining zone of Minas had a relatively high child-to-woman ratio. In his study of Constituição (Piracicaba), Motta (2006) calculates that the male-to-female ratio of the slave population was 1.8 to 1 in $1854,1.3$ to 1 in 1874 and 1.4 to 1 in 1886 , compared with statistics for the overall free population of 0.9 to $1,1.0$ to 1 and 0.9 to 1 , respectively.

Manumission rates increased over time, and the free African or Mulatto population expanded relative to the slave, even as slave imports accelerated. Schwartz (1974) examines 1,015 "letters of freedom» registered in Salvador, Bahia, between 1684 and 1745: across this sample, the ratio of femaleto-male manumitted slaves was 2 to 1 , and Mulattos were far over-represented relative to their share of the slave population. In their study, Libby and Paiva (2000) also observe that manumission was most common among female adult slaves.

Although slave populations exhibited higher mortality and lower fertility, their natural growth was not always negative: in late $18^{\text {th }}$-century Minas Gerais, for instance, many slaves were native-born, resulting in a relatively equal sex distribution and positive natural growth (Klein and Luna 2004); such was also the case in Paraná earlier that century (Gutiérrez 1987). Nonetheless, this was more typical of the free population; during the $16^{\text {th }}$ and $17^{\text {th }}$ centuries, most people of African descent were slaves and suffered high mortality in the mines and plantations (Klein and Luna 2010). Even by 1872, slaves made up 26 per cent of all Africans/Mulattos, and their life expectancy was nearly ten years below average (Merrick and Graham 1979).

Martins Filho and Martins (1983) attribute the rapid increase of the slave population in Minas Gerais from 1808 to 1872 to slave imports, not natural growth. The analysis considers rates of natural increase for the slave population of -2 per cent or less - a magnitude they support with reference to Goulart, who estimates rates of -3 per cent and -4 per cent for the periods 1717-1723 and 1723-1735, and Eschwege, who calculates - 2.2 per cent and -3.9 per cent for Mulatto and African slaves in 1820.

The sex-and-age distribution of the interior slave population became more equal over time, opening the possibility for positive natural rates of increase by the $19^{\text {th }}$ century; however, this high fertility may not have been able to fully offset the elevated mortality of a mostly male slave population (Klein and Luna 2004). During the $16^{\text {th }}$ century, when almost all Africans in Brazil were slaves, a conservative rate of natural increase would be -5 per cent; in the $17^{\text {th }}$ century, conditions may have marginally improved to 
about -4 per cent; in the $18^{\text {th }}$ century, the rate of decline was probably closer to 2 per cent; and, in the $19^{\text {th }}$ century, the combined free/slave African or Mulatto rate of growth was near-zero (Merrick and Graham 1979).

I use these growth rates, starting values from the text, and annual imports to calculate a benchmark African population for each region across the ten periods of study ${ }^{15}$. This approach recognises the rising numbers of manumitted and native-born slaves, mostly women, whose fertility gradually permitted the population of African descent to stabilise within the context of persistently high mortality. For the $17^{\text {th }}$ century, I obtain the following figures - Bahia: 6,200 "Africans» as of 1625 and 25,400 in 1675; and Pernambuco: 9,100 in 1625 and 43,700 in 1675.

\section{Discussion and consolidated figures}

During the $17^{\text {th }}$ century the Portuguese pushed the frontier westward, settling large portions of South America, including the north coast and lower Amazon. In the São Paulo area, slave-hunting activity peaked and non-captive Natives disappeared from the region (Hemming 1987). My projections for 1625 show that the Native population numbers may be exaggerated (40,000 in Maranhão and São Vicente vs. estimates of 5,600 and 11,400); however, they cannot be dismissed because slaves were often captured at a distance and brought into the settlements. For 1675, these two sets of figures are closer: compare the observed 25,000 Natives in Pará with 32,600 projected; as many in Maranhão against 13,900; and, 20,050 in São Vicente with 22,500.

Similarly, the estimated African population is relatively close to available first-hand observations: for 1625, the 5,000 Africans cited in Pernambuco compare with 10,840 based on sugar production or 9,100 using slave imports; for 1675, the 25,000 observed in Bahia compare with a projection of 25,400 using slave trade data; notably, for Bahia in 1625 , the slavetrade- and production-based estimates exactly coincide. I present a fuller portrait of Brazil's population in Table 6 by combining the «observed» and estimated population statistics.

In the $17^{\text {th }}$ century, the racial composition of Luso-Brazil was not hugely different than it was 100 years earlier - Natives generally outnumbered Europeans, who surpassed Africans - yet it was more even. With the exception of the north and south (where Natives prevailed) and the traditional northeast sugar zone (where Africans were a majority), the indigenous population of the settlements was flat compared with the rapid increase of European and African populations.

${ }^{15}$ As starting values, I use contemporary observations of the African population preceding the first-recorded slave shipment: 1675, 100 in Amazonas; 1585, 3,665 in Bahia and 5,665 in Pernambuco; 1675, 2,500 in Southeast Brazil. 
TABLE 6

CONSOLIDATED POPULATION OF «BRAZIL»BY RACE (CA. 1625, 1675)

\begin{tabular}{|l|c|r|r|r|r|r|}
\hline & \multicolumn{5}{|c|}{1625} & \multicolumn{1}{c|}{1675} \\
\hline Captaincy & Native $^{\mathbf{3}}$ & \multicolumn{1}{|c|}{ European $^{\mathbf{1}}$} & African $^{\mathbf{2}}$ & Native $^{\mathbf{3}}$ & European $^{\mathbf{1}}$ & African \\
\hline Pará & 13,100 & 200 & 0 & $25,000^{1}$ & 500 & $100^{1}$ \\
\hline Maranhão & $40,000^{1}$ & 1,500 & 0 & $25,000^{1}$ & 1,000 & $100^{1}$ \\
\hline Rio Grande & 6,000 & - & 160 & 7,900 & - & - \\
\hline Itamaracá/Paraíba & 4,700 & 4,980 & 3,400 & 6,000 & - & - \\
\hline Pernambuco & 11,100 & 66,000 & 10,840 & 14,600 & - & $43,700^{4}$ \\
\hline Sergipe & 3,200 & 2,400 & 640 & 3,300 & - & - \\
\hline Bahia/Ilhéus & 12,600 & 18,350 & 6,200 & 21,000 & - & $25,000^{1}$ \\
\hline Espírito Santo & 900 & 2,400 & 640 & 800 & - & - \\
\hline Rio de Janeiro & 1,600 & - & 4,800 & 1,900 & - & - \\
\hline São Vicente & $40,000^{1}$ & 2,000 & 160 & $20,050^{1}$ & 8,900 & - \\
\hline Total & $70,100-133,200$ & $>97,830$ & 26,840 & 125,500 & $?$ & $>68,900$ \\
\hline
\end{tabular}

Sources: ${ }^{1}$ Figures obtained from $17^{\text {th }}$-century documents, averaged when multiple sources available.

${ }^{2}$ Estimated African population based on the number of sugar plantations recorded by contemporaries.

${ }^{3}$ Unless otherwise indicated, projected Native headcount based on initial population, areas settled, and annual growth rate of $-0.37 \%$.

${ }^{4}$ Projected African headcount based on estimated slave imports from Trans-Atlantic Slave Trade Database and negative $4 \%$ annual population growth rate.

\section{THE GOLD ERA}

Gold was discovered during the late $17^{\text {th }}$ century by the bandeirantes during their expeditions and a "gold-rush of epic proportions» began with the discovery of Ouro Prêto in 1701 (Hemming 1978). Gold production would dominate the new interior captaincies of Minas Gerais, Mato Grosso and Goiás during the next 50 years (Russell-Wood 1987). The gold boom led to the enslavement or flight of local Natives, the stepping up of African slave imports and the immigration of thousands of Europeans in search of fortune.

\subsection{Extant statistics}

I describe the racial composition of the captaincies for two periods, centred on 1725 and 1775. Population statistics for Pará and Maranhão are from Jesuit documents in Leite (1938) and a letter from the Governor of Maranhão-Pará to the Secretary of State to the King (ca. 1755). Figures for 
TABLE 7

THE POPULATION OF «BRAZIL»DURING THE $18^{\text {TH }}$ CENTURY

\begin{tabular}{|c|c|c|c|c|c|c|}
\hline & \multicolumn{3}{|c|}{$1725^{1}$} & \multicolumn{3}{|c|}{$1775^{2}$} \\
\hline Captaincy & Native & European & African & Native & European & African** \\
\hline Pará & 51,216 & 12,000 & $2-3,000$ & 28,391 & \multicolumn{2}{|c|}{37,310} \\
\hline Maranhão & - & - & - & - & 15,366 & 32,048 \\
\hline Piauí & - & - & - & \multicolumn{3}{|c|}{ total 26,410} \\
\hline Ceará & - & - & - & \multicolumn{3}{|c|}{ total 61,408} \\
\hline Rio Grande do Norte & - & - & - & \multicolumn{3}{|c|}{ total 23,812} \\
\hline Paraíba & - & - & - & \multicolumn{3}{|c|}{ total 52,468} \\
\hline Pernambuco & - & - & - & \multicolumn{3}{|c|}{ total 239,713} \\
\hline Bahia & - & $>18,000$ & - & - & 72,212 & 216,636 \\
\hline Minas Gerais & - & - & $>30,000$ & - & 76,664 & 243,105 \\
\hline Mato Grosso & 2,200 & 2,200 & 2,600 & 797 & 3,313 & 16,857 \\
\hline Rio de Janeiro & \multicolumn{3}{|c|}{ total 40,000} & \multicolumn{3}{|c|}{ total 215,678} \\
\hline São Paulo* & - & 一 & - & & 65,974 & 51,001 \\
\hline Santa Catarina & - & - & - & \multicolumn{3}{|c|}{ total 10,000} \\
\hline Rio Grande de S. Pedro & - & - & - & \multicolumn{3}{|c|}{ total 20,309} \\
\hline Total & - & - & - & \multicolumn{3}{|c|}{$>1,564,986$} \\
\hline
\end{tabular}

Sources: ${ }^{1}$ Jesuit documents in Suma Histórica (Leite, 1938-1950), Letter of Governor Mendonça Furtado to Pombal, Cultura e Opulencia do Brasil (Antonil 1711), Codice Costa Matoso, and Letter of Archbishop of Bahia to Crown.

${ }^{2}$ Alden (1963), «The Population of Brazil in the Late 18th Century: A Preliminary Study».

Notes: *São Paulo was now recognized as a separate province spanning former areas in São Vicente.

**The census category «Mulatto» is included in the «African» population to allow for comparison with earlier figures.

Minas Gerais and Mato Grosso are based on Antonil (1711) and slave matriculations in Codice Costa Matoso (Boxer 1962, pp. 181-187). For Rio de Janeiro and São Paulo, I refer to a letter of the Archbishop of Bahia (1702).

All data for 1775 are from regional census and parish records as compiled by Alden (1963). The combined figures for both periods are presented in Table 7. There is a lack of information for the period ca. 1725, yet it appears that the Native population of the north had not diminished from its 1675 level and a large African contingent centred in Minas Gerais. Towards the end of the century, there was a concerted effort to gauge the overall population yet, Alden explains, it was at the discretion of the provincial governors whether or not to collect racial information. 


\subsection{Production-based estimates}

In the interior captaincies, gold lured settlers and created a demand for slaves. Most gold was produced from placer mining (rocking river sediment in a pan) with low capital investment; eventually hydraulic pumps were adopted to work the hillsides or riverbeds and sluice boxes came into use (Russell-Wood 1987). As the century progressed, yields diminished notably: productivity ranged from as much as 100 s of drams $(1 \mathrm{dr}=1 / 8 \mathrm{oz})$ of gold a year to as few as twenty by 1780 (Coelho; in Boxer 1962).

As with sugar, gold production had large demographic effects. I calculate average gold output by decade for Minas Gerais based on Noya Pinto (1979), as reprinted in Alden (1984). Supposing that available population figures are correct: there were about 30,000 African slaves in Minas Gerais in the 1710s (Russell-Wood 1987); an average 98,730 and 93,328 registered slaves in the 1730s and 1740s (Codice Costa Matoso; in Boxer 1962); and an African/ Mulatto population of 243,000 in the 1770 s, and 369,000 in the 1790 s (Alden 1963). It follows that average annual gold production per person was $\sim 111 \mathrm{dr}$ in the 1710s, 47 and $54 \mathrm{dr}$ for the 1730s and 1740s, $12 \mathrm{dr}$ during the $1770 \mathrm{~s}$, and $5 \mathrm{dr}$ in the $1790 \mathrm{~s}^{16}$.

These per-capita estimates are congruent with those of Boxer, Coelho, and Russell-Wood (27-81 dr p.p. in 1720s/1730s; 20 dr in 1780s), and Goulart (36-41 dr p.p. from 1735 to 1760). Since the downward trend in production per capita was steady, a fair estimate of the African slave population of Minas Gerais in intermediate years is possible. In the 1720s, for instance, 3.7 million drams of gold were produced $(14,500 \mathrm{~kg})$; imputed output per capita - based on adjacent decades' productivity and contemporary figures — was near $80 \mathrm{dr}$; the African slave population may therefore have been around 47,000.

For the coastal captaincies, the value of sugar produced continued to exceed that of gold; however, there were some industrial changes which must be accounted for. Schwartz (1987) writes that the average size and productivity of sugar plantations declined from the late $17^{\text {th }}$ into the $18^{\text {th }}$ century. His figures indicate that average output per engenho was only 2,265 arrobas (one arroba $=14.4 \mathrm{~kg}$ ) for the $18^{\text {th }}$ century, compared with nearly 4,000 previously. Stein (1985) argues that smaller plantations were less productive because of soil degradation, meaning fewer slaves producing less sugar: perhaps only 40 arrobas per worker compared with 50 the previous century. Building on these assumptions, I estimate the slave workforce based on the level of productivity and either the number of plantations or total output.

In 1725, 2.5 million arrobas of sugar were produced in Brazil (Burlamaqui 1862) with a slave labour force of 62,500 based on 40 arrobas per worker.

16 The average annual gold output from Noya Pinto (1979; in Alden 1984) is as follows: 1710s, 3.3 million drams; 1730s, 4.7 million drams; 1740s, 5.1 million drams; $1770 \mathrm{~s}, 3.0$ million drams; and, 1790s, 1.7 million drams. 
At the time, there were 139 engenhos in Bahia (Schwartz 1985), corresponding to almost 8,000 slaves $^{17}$. Alden (1984) cites 286 plantations in PernambucoParaíba; by my calculation, there would have been over 16,000 slaves. In 1775, only 1.4 million arrobas of sugar were produced across Brazil (Burlamaqui), with 35,000 slaves possibly employed. Alden reports at least 170 engenhos in Bahia, 390 in Paraíba-Pernambuco, and 104 in Rio de Janeiro - 9,600, 22,000 and 5,900 ensuing slaves.

\subsection{Discussion and consolidated figures}

The inward expansion of the Brazilian domain had important implications for Native and African populations: as gold production rose, Natives were enslaved or displaced and the volume of the African trade grew. During the $18^{\text {th }}$ century, there are registered slave shipments for over half of all years - a total of 1,755 voyages. According to TASTD estimates, 2.2 million African slaves were imported; my benchmark, assuming half of voyages were recorded, is 1.1 million.

How do contemporaries' figures and regional census data for 1725 compare with my output, slave trade, and initial-density-based estimates of African and Native populations? For Pará-Maranhão, slave import records indicate an African population of 5,685 compared with 2-3,000 «observed»; the Native projection is 61,500 against 51,216 observed. For Minas Gerais, an estimated 50,000 African slaves were in the gold sector contrasted with supposedly 30,000 ten years earlier. Finally, the projected Native population of 7,600 in Mato Grosso is weighed against 2,600 observed.

For 1775, I estimate 76,000 Natives for Pará but fewer than 30,000 are recorded by contemporaries; slave voyage registers suggest up to 50,000 people of African descent in Pará-Maranhão compared with 34,000 observed. Gold output in Minas Gerais implies 150-250,000 «Africans» against the 243,105 Africans/Mulattos of the census; the combined projection of 476,600 in Bahia, Minas Gerais and Mato Grosso compares with a recorded 280,300. Finally, my estimate of 18,200 Natives in Mato Grosso compares to only 797, and 30,300 Africans in São Paulo compares to 51,001, in the census.

I add my estimates to the historical statistics, for years when these are lacking, and obtain the collected figures presented in Table 8. While contemporary documents describe Native or African headcounts in only twoto-three provinces, one may conclude there were at least 180,000 Natives and over 100-150,000 people of African descent across Brazil in 1725. With the exception of Minas Gerais, the Native population continued to exceed the African. By 1775, however, the African or Mulatto population rose to nearly

17 This follows from the calculation: 2,265 arrobas per plantation $\times 139$ plantations $\div 40$ arrobas per worker. 
TABLE 8

CONSOLIDATED POPULATION OF «BRAZIL» BY RACE (CA. 1725, 1775)

\begin{tabular}{|c|c|c|c|c|c|c|}
\hline & \multicolumn{3}{|c|}{1725} & \multicolumn{3}{|c|}{1775} \\
\hline Captaincy & Native $^{3}$ & European & African & Native $^{3}$ & European & African \\
\hline Pará & $51,216^{1}$ & $12,000^{1}$ & $3,000^{1}$ & $28,391^{1}$ & \multicolumn{2}{|c|}{$37,310^{1}$} \\
\hline Maranhão & - & - & - & 12,200 & $15,366^{1}$ & $32,048^{1}$ \\
\hline Piauí & 8,500 & - & - & 10,600 & \multicolumn{2}{|c|}{$15,800^{*}$} \\
\hline Ceará & 9,400 & - & - & 11,700 & \multicolumn{2}{|c|}{$49,700 *$} \\
\hline Rio Grande do N. & 8,200 & - & - & 7,500 & \multicolumn{2}{|c|}{$16,300^{*}$} \\
\hline Paraíba & 6,200 & - & $16,195^{2}$ & 5,600 & \multicolumn{2}{|c|}{$46,900 *$} \\
\hline Pernambuco & 17,700 & - & - & 15,100 & $75-112,000 * *$ & $92-150,000^{4}$ \\
\hline Bahia & 27,900 & $>18,000^{1}$ & $7,871^{2}$ & 30,700 & $72,212^{1}$ & $216,636^{1}$ \\
\hline Minas Gerais & 14,300 & - & $50,000^{2}$ & 16,700 & $76,664^{1}$ & $243,105^{1}$ \\
\hline Mato Grosso & $2,200^{1}$ & $2,200^{1}$ & $2,600^{1}$ & 18,200 & $3,313^{1}$ & $16,857^{1}$ \\
\hline Espírito Santo & 600 & - & - & 700 & - & - \\
\hline Rio de Janeiro & 2,300 & - & $14,891^{4}$ & 2,400 & \multicolumn{2}{|c|}{$213,278^{*}$} \\
\hline São Paulo & 13,400 & - & - & 12,700 & $65,974^{1}$ & $51,001^{1}$ \\
\hline Santa Catarina & 10,300 & - & - & 9,500 & \multicolumn{2}{|c|}{$500 *$} \\
\hline Rio Grande do S. & 8,200 & - & - & 15,000 & \multicolumn{2}{|c|}{$5,300 *$} \\
\hline Total & 180,400 & - & $>94,500$ & 197,000 & $>482,500 * *$ & $>966,000 * *$ \\
\hline
\end{tabular}

Sources: ${ }^{1}$ Figures obtained from 18 th-century documents or corroborated secondary sources.

${ }^{2}$ Estimated «African» population based on the number of sugar plantations or gold output.

${ }^{3}$ Unless noted otherwise, Native projections based on initial population, areas settled, and annual growth rate of $-0.37 \%$.

${ }^{4}$ Projected «African» headcount from slave imports in Trans-Atlantic Slave Trade Database and $-2 \%$ annual natural rate of increase.

Notes: *Difference between the total population (in Alden 1963) and projected Native population.

**Absent other information for individual provinces, total presumes a 2:1 African-to-European split.

1 million (still notably fewer than the cumulative number of slaves imported thus far) and, for the first time, Natives were a clear minority.

\section{THE COFFEE ERA}

At the beginning of the $19^{\text {th }}$ century, the colonial era was ending and the economy became increasingly diversified into other staples - notably coffee, 
but also tobacco, cacao, cotton and rice (Alden 1984). French troops invaded Portugal in 1807 and the royal court took refuge in Rio de Janeiro; in 1822, after the King had returned to Europe, his son Pedro I declared himself Emperor of an independent Brazil (Merrick and Graham 1979).

The international slave trade was forcibly halted by the British in 1850 (Goulart 1975), but the internal trade was thriving and would not be abolished until 1888 (Bethell 1970). There is no recorded Italian or Spanish immigration, only Portuguese, in the first half of the century (Instituto Brasileiro de Geografia e Estadística (IBGE). The population of Brazil, by state and race, will be examined for three additional periods $-1800,1825$ and 1850 - during the pre-statistical era.

\subsection{Extant statistics}

The main contemporary data sources are: a letter from Lord Strangford to Marquis of Wellesley dated May 20, 1810 (in Alden 1984); Paraíba, Mapa de População, 1798 (Marcílio 1984); and Souza e Silva, População Geral do Império, documents in the Arquivo Nacional de Rio de Janeiro and IHGB/CU, and Octávio Ianni, Metamorfoses (in Klein and Luna 2010) ${ }^{18}$. The compiled census figures from these sources are presented in Table 9.

Between 1775 and 1800, the Native population declined while the populations of European and African descent increased (to roughly 5 per cent «Native», 30 per cent «European» and 65 per cent «African or Mulatto»). Overall, the population grew by over 40 per cent and 60 per cent in the quarter-centuries preceding 1825 and 1850. For these periods, the racial distribution is unclear so the column totals in Table 9 are only lower bounds. Available data suggest, however, that Africans and Mulattos continued to form a majority. Less new land was settled, so fewer Natives were incorporated into Brazilian society, and their population growth centred in the southeast.

\subsection{Production-based estimates}

If the $16^{\text {th }}$ and $17^{\text {th }}$ centuries were those of sugar, and the $18^{\text {th }}$ that of gold, then the $19^{\text {th }}$ belonged to coffee. The first plantations were established during the mid-18 ${ }^{\text {th }}$ century in São Paulo and production spread to Rio de Janeiro, Minas Gerais and Espírito Santo (Filho 1952). Coffee production burgeoned in the 1790s, becoming the country's most valuable export by the 1830 s (Bethell and Carvalho 1989).

18 These data are corroborated by Velloso de Oliveira, Memória. Complementary sources include Goulart (1975), citing the National Library archives, and Metcalf (1992), referring to the 1820 census records for Parnaíba. 
TABLE 9

THE POPULATION OF «BRAZIL» DURING THE EARLY-TO-MID $19^{\text {TH }}$ CENTURY

\begin{tabular}{|c|c|c|c|c|c|c|c|c|c|}
\hline & \multicolumn{3}{|c|}{$1800^{1}$} & \multicolumn{3}{|c|}{$1825^{2}$} & \multicolumn{3}{|c|}{$1850^{3}$} \\
\hline State & Native & European & $\begin{array}{l}\text { African/ } \\
\text { Mulatto }\end{array}$ & Native & European & $\begin{array}{l}\text { African/ } \\
\text { Mulatto }\end{array}$ & Native & European & $\begin{array}{l}\text { African/ } \\
\text { Mulatto }\end{array}$ \\
\hline Amazonas & - & - & - & \multicolumn{3}{|c|}{19,350} & 23,339 & 3,454 & 13,791 \\
\hline Pará & 16,000 & 21,160 & 42,320 & \multicolumn{3}{|c|}{123,901} & \multicolumn{3}{|c|}{179,707} \\
\hline Maranhão & 3,943 & 24,447 & 49,918 & \multicolumn{3}{|c|}{200,000} & \multicolumn{3}{|c|}{282,154} \\
\hline Piauí & 13,915 & 12,854 & 32,193 & \multicolumn{3}{|c|}{84,847} & \multicolumn{3}{|c|}{152,891} \\
\hline Ceará & - & - & - & \multicolumn{3}{|c|}{201,170} & \multicolumn{3}{|c|}{503,759} \\
\hline Rio Grande N. & \multicolumn{3}{|c|}{70,921} & 3,103 & 27,638 & 49,789 & 6,785 & 48,157 & 94,130 \\
\hline Paraíba & 2,817 & 8,930 & 19,268 & 3,405 & 45,208 & 73,794 & \multicolumn{3}{|c|}{212,466} \\
\hline Goiás & 2,882 & 6,928 & 45,668 & 994 & 11,761 & 55,742 & \multicolumn{3}{|c|}{79,339} \\
\hline Mato Grosso & 1,020 & 4,240 & 21,576 & 2,733 & 4,278 & 25,654 & \multicolumn{3}{|c|}{54,558} \\
\hline Paraná & - & 18,340 & 16,600 & 85 & 23,895 & 18,910 & - & 33,633 & 28,625 \\
\hline Pernambuco & 12,544 & 111,716 & 267,334 & \multicolumn{3}{|c|}{348,465} & 2,094 & 90,291 & 195,271 \\
\hline Alagôas & - & - & - & \multicolumn{3}{|c|}{111,973} & 6,603 & 56,797 & 144,366 \\
\hline Sergipe & - & - & - & \multicolumn{3}{|c|}{114,996} & 1,485 & 43,542 & 92,716 \\
\hline Bahia & 5,392 & 71,169 & 282,517 & \multicolumn{3}{|c|}{477,912} & \multicolumn{3}{|c|}{812,920} \\
\hline Espírito Santo & & 72,845 & & 3,518 & 6,730 & 15,832 & 6,732 & 9,994 & 11,726 \\
\hline
\end{tabular}


TABLE 9 (Cont.)

\begin{tabular}{|l|c|c|c|c|c|c|c|c|c|}
\hline & \multicolumn{3}{|c|}{$\mathbf{1 8 0 0}^{\mathbf{1}}$} & \multicolumn{3}{|c|}{$\mathbf{1 8 2 5}^{\mathbf{2}}$} & \multicolumn{3}{|c|}{$\mathbf{1 8 5 0}^{\mathbf{3}}$} \\
\hline State & Native & European & $\begin{array}{l}\text { African/ } \\
\text { Mulatto }\end{array}$ & Native & European & $\begin{array}{l}\text { African/ } \\
\text { Mulatto }\end{array}$ & Native & $\begin{array}{c}\text { African/ } \\
\text { European }\end{array}$ \\
\hline Rio de Janeiro & 4,592 & 77,140 & 147,621 & 5,615 & 112,973 & 288,604 & 4,952 & 160,945 & 390,183 \\
\hline Minas Gerais & 8,906 & 116,763 & 369,090 & \multicolumn{3}{|c|}{631,885} & \multicolumn{3}{|c|}{$1,263,667$} \\
\hline São Paulo & 6,264 & 116,932 & 85,611 & - & 131,330 & 116,574 & - & 172,879 & 153,198 \\
\hline Rio Grande S. & 22,583 & 26,834 & 17,601 & 8,655 & 32,300 & 26,010 & \multicolumn{4}{|c|}{149,363} \\
\hline Santa Catarina & - & 23,680 & 7,854 & 839 & 37,470 & 13,871 & 136 & 45,596 & 17,894 \\
\hline Other (Corte) & - & 19,578 & 23,798 & \multicolumn{7}{|c|}{112,695} & & 266,466 \\
\hline Total & $>100,858$ & $>660,711$ & $>1,428,969$ & $>28,947$ & $>433,583$ & $>684,780$ & $>52,126$ & $>665,288$ & $>1,141,900$ \\
\hline
\end{tabular}

Sources: ${ }^{1}$ Alden (1984), «Late Colonial Brazil, 1750-1808»; ratio of free-to-slave Africans in Pará may have been 1.3 to 1, as in other areas Alden points to 18,400 African slaves in Pará, so there might be 23,920 free «Africans» or 42,320 of African descent; Hemming (1978) implies that the ratio of Africans-to-Europeans in Pará was 2:1, or 21,160 Europeans; Marcílio (1984) cites the AHU (Paraíba, Mapa de População, sheaf 20, doc. 38) 1798 census figures; for Paraíba (IHGB/CU, Arq. 1-1-13, fols. 148v-149), and Paraná, Santa Catarina, Rio Grande do Norte and Espírito Santo (Souza e Silva 1870), observations in Klein and Luna (2010).

${ }^{2}$ Souza e Silva, População Geral do Império (1870); ANJR, cod. 808, I (fols. 35, 96) and III (fols. 38, 39, 93); in Klein and Luna.

${ }^{3}$ Souza de Silva (1870), Ianni (Metamorfoses, 1962), and the National Archives of Rio de Janeiro (ANJR, cod. 808, III, fol. 86); also in Klein and Luna. 
Cultivating coffee was very labour-intensive. Slaves were used to plant and tend trees (thousands per person), harvest and transport the cherries, and dry, remove, and sort the beans (Stein 1985). A typical coffee plantation (fazenda) had an area from 500 to 1,000 ha but employed fewer than 100 slaves $^{19}$. As productivity per tree varied, so did productivity per slave: output ranged anywhere from 300 to $3,000 \mathrm{~kg}$ of coffee per worker, depending on the quality of the soil, age of trees and efficiency of production ${ }^{20}$.

Based on the average annual output reported by Alden (1984) and Soares (1860), I estimate the number of slaves producing coffee in each state, assuming produce-per-slave of $1,500 \mathrm{~kg}$ ( $\sim 100$ arrobas $)$, the midpoint of recorded yields. By this measure, fewer than 1,000 slaves were directly producing coffee at the turn of the century, but by 1825 , an estimated 10,700 slaves were on the fazendas of Rio de Janeiro alone; by 1850 , about 88,500 slaves were producing coffee across Brazil, with 72,000 in Rio de Janeiro and 1,200 in Bahia ${ }^{21}$.

As coffee production was increasing, the sugar sector experienced its own expansion from the 1790s to 1820s (Schwartz 1985; Bethell and Carvalho 1989). At the beginning of the century, there were 260 engenhos in Bahia, 140 in Sergipe and 616 in Rio de Janeiro (Alden 1984; Schwartz 1985). Based on the level of productivity described earlier, this would correspond to 22,650 slaves in Bahia/Sergipe and 34,881 in Rio de Janeiro as of 1800 .

Small sugar plantations proliferated, yet there is no evidence that production per slave changed. With output figures from Soares (1860), assuming 40 arrobas per slave, I infer that there were about 13,000 slaves producing sugar in Pernambuco in 1800; in 1825, 29,000 in Rio de Janeiro, 32,000 in Bahia, and 23,000 in Pernambuco; and in 1850, 218,000 in Brazil, with 73,000 in Bahia and 96,000 in Pernambuco ${ }^{22}$. Dozens of products were produced by slaves, thus these numbers only reflect a lower bound for the slave population.

19 According to Stein (1985), the typical plantation in Vassouras had eighty to 100 slaves in the late $19^{\text {th }}$ century. Klein and Luna (2010) cite an average 43 per fazenda in Rio de Janeiro in the early 1880s (based on Van Delden Laerne 1885) with an area of 645 ha. Klein (2010) concludes that the typical plantation had seventy to 100 slaves, and Filho (1952) describes a fazenda as generally over 500 ha with several dozen families of workers.

20 Klein and Luna (2010) refer to output of only $400 \mathrm{~kg} / \mathrm{slave}$ on «early farms»; their data also indicate an average productivity of $957 \mathrm{~kg} / \mathrm{slave}$ in São Paulo in 1854 (Machado de Oliveira). On the most-productive fazendas in late-18th-century São Paulo, Carvalho de Mello (1977) calculates an average 33.6 sacks/slave (about 2,016 kg/slave); Filho (1952) puts the average yield in São Paulo at 20 to 50 arrobas $(1$ arroba $=14.4 \mathrm{~kg})$ per 1,000 trees.

21 In 1800-1807, average coffee output per year in Pernambuco was 4,910 kg; in Bahia, 68,342 kg; in Rio de Janeiro, 787,536 kg; and in Pará, 57,096 kg (Alden 1984). In 1825, annual production in Rio de Janeiro was 16,085,203 kg; in 1850, in Brazil 132,795,259 kg, with $107,957,722 \mathrm{~kg}$ in Rio de Janeiro and 1,741,320 kg in Bahia (Soares 1860).

22 Average annual sugar exports in Pernambuco were 526,167 arrobas in 1800-1804; in 1825-1829, 1,173,343 in Rio de Janeiro, 1,289,616 in Bahia, and 913,992 in Pernambuco; and in 1850-1854, in Brazil 8,706,162 arrobas, with 2,935,752 in Bahia and 3,844,894 in Pernambuco (Soares 1860). 


\subsection{Discussion}

Although approaching the modern era, Brazil had not realised its present political and territorial form - the frontier continued to shift into the interior and Natives gradually came into contact. The Native population appears stable but continued its downward trend. The African population, however, experienced an unprecedented augment: According to TASTD, almost 50 per cent of all slaves were brought to Brazil during the first half of the $19^{\text {th }}$ century ${ }^{23}$.

At this point, it is difficult to compare the regional census figures with those based on production, slave imports, or the pre-Columbian population: racial distinctions are increasingly arbitrary; sugar, gold and coffee no longer constitute the bulk of economic activity; and forward projections are imprecise. Nonetheless, these alternative estimates are consistent with the census data and provide supplementary information on both the racial makeup of the population and the workforce's servile status across key economic sectors.

Around 1800, for instance, only 8 per cent of the combined African/ Mulatto population in Bahia was producing sugar; in Pernambuco, 5 per cent; and, in Rio de Janeiro, 24 per cent ${ }^{24}$. In 1825 , just 22 per cent of slaves in Bahia were making sugar; in Pernambuco, 30 per cent; in Rio de Janeiro, across coffee and sugar, 18 per cent; and, in Brazil, no more than 40 per cent of the slave labour force was involved in either sugar or coffee ${ }^{25}$. By 1850 , 49 per cent of Pernambuco's African/Mulatto population was in sugar, whereas in Rio de Janeiro there was just 5 per cent in the sugar (and 18 per cent in the coffee) sector ${ }^{26}$.

The total Native population recorded in the census across states with data was 100,858, 28,947 and 52,126 for 1800, 1825 and 1850 (my corresponding projections for just those states are 174,900, 63,400 and $78,400)$. If I substitute missing values by my estimates, the total Native population of the territory of Brazil was 177,900, 221,400 and 231,200 in these periods.

231.11 million African slaves were imported to Brazil from 1800 to 1824 , and 1.29 million from 1825 to 1850 .

${ }^{24}$ Of the African or Mulatto population of 282,517 (168,935 of whom were slaves) in Bahia ca. 1800, I calculate that 22,650 were making sugar; in Pernambuco, the population of African descent was 267,334, with 13,000 in the sugar sector; in Rio de Janeiro, of 147,621 people of African descent $(105,378$ slaves), only 34,881 were in sugar.

25 In Bahia ca. 1825, of 147,263 slaves, about 32,000 produced sugar; in Pernambuco, of 77,633 slaves, 23,000; in Rio de Janeiro, of 224,012 slaves (288,604 of African descent), the sugar and coffee sectors employed 40,000; and, across Brazil, there were 813,052 slaves, with 88,500 in coffee and up to 218,000 in sugar production.

${ }^{26}$ In Pernambuco ca. 1850, of an African/Mulatto population of 195,271 (68,458 slaves), 96,000 were employed in sugar; in Rio de Janeiro, of 390,183 (293,554 slaves), an estimated 72,000 made coffee or 90,000 including sugar. 
I also compare my regional slave-import estimates of the African and Mulatto population with the census figures ${ }^{27}$. The census data are the most reliable source of information on Brazil's population during the $19^{\text {th }}$ century; alternative population estimates are suggestive of, but cannot supply precise details on, each state's racial makeup. While the number of slaves is extensive, their share of the total population declined to roughly one-quarter by 1850 . Sugar, gold and coffee continued to be important, slave-intensive sectors of the economy; however, slaves were also employed in other occupations, ranging from merchants to whalers (Klein and Luna 2010).

\section{CONCLUSION}

A more-formal demographic analysis is not feasible because the data are coarse in nature, having been assembled from a variety of sources along somewhat arbitrary racial arrays. They are, nonetheless, suggestive of major demographic shifts and, when complemented with other information (ethnographies, slave import records, commodity output, etc.), can accurately define the historical contours of race in Brazil.

\subsection{Racial transitions}

The consolidated population figures presented here provide demographic data for eight captaincies (states) during the $16^{\text {th }}$ century, ten during the $17^{\text {th }}$ century, fifteen in the $18^{\text {th }}$ century and twenty for the $19^{\text {th }}$ century, although racial breakdowns are not always available. In Table 10, I trace the overall size of each racial group through the colonial and early imperial $\mathrm{eras}^{28}$.

The population of African descent exceeded the indigenous in Europeansettled areas between 1725 and 1775, and probably before 1750. Table 10 also indicates that the total population grew at an average annual rate of 1.7 per cent from 1545 to 1725 , and 2.0 per cent from 1725 to 1850 - relatively high growth comparable to that of the United States (Merrick and Graham 1979). The transition from Native to African labour occurred first in the northeast, followed by the central-west, southeast and north, in parallel with the rise of sugar, gold and coffee as major exports.

27 In 1800, the "African» population of Amazonia was 123,431 compared with my 76,500 benchmark; in Pernambuco, 327,544 vs. 96,100; in Bahia, 718,851 vs. 374,900; and, in southeast Brazil, 311,710 vs. 87,600 . In 1825, the African/Mulatto population of Pernambuco was 411,301 compared with my 155,600; in Bahia, 636,295 vs. 656,900; and, in the southeast, 479,801 vs. 871,600 . In 1850, the population of African descent in Pernambuco was 632,716 vs. an estimated 266,700; and, in the southeast, 670,902 vs. $1,984,700$.

${ }^{28}$ For states without $19^{\text {th }}$-century racial breakdowns, I assume that the relative size of each group was the same as during the previous period. This evens out changes in racial makeup over time, but the introduced bias does not mask aggregate shifts in racial composition driven in-part by new and evolving states. 
TABLE 10

THE POPULATION OF «BRAZIL» BY RACE, 1545-1850

\begin{tabular}{|l|c|c|c|c|}
\hline & Native & European & African & Total \\
\hline 1545 & 18,700 & 3,000 & 1,780 & 23,480 \\
\hline 1570 & 50,800 & 20,760 & 4,960 & 76,520 \\
\hline 1585 & 25,435 & 30,060 & 11,430 & 66,925 \\
\hline 1625 & 133,200 & 97,830 & 26,840 & 257,870 \\
\hline 1675 & 125,500 & $125,000 * * *$ & 68,900 & 319,400 \\
\hline 1725 & 180,400 & $200,000 * * *$ & $134,500 * * *$ & 514,900 \\
\hline 1775 & 197,000 & 482,500 & 966,000 & $1,645,500$ \\
\hline $1800 *$ & 113,425 & 703,845 & $1,517,034$ & $2,334,304$ \\
\hline $1825^{*}$ & 129,545 & $1,009,882$ & $2,233,585$ & $3,574,182^{* *}$ \\
\hline $1850 *$ & 204,367 & $1,584,997$ & $3,522,949$ & $5,816,072 * *$ \\
\hline
\end{tabular}

Notes: *Absent state-level data, racial makeup of proximate year used.

**Includes Ceará: 1825 population $-201,170$, and $1850-503,759$.

***Author's estimate based on available data.

\subsection{Discussion}

The early history of Brazil is one of three peoples of distinct ancestry: Indigenous, European and African. After settlement began in the 1530s, the land's original inhabitants were enslaved and their labour helped sustain the colonies; rising demand and falling Native numbers prompted the importation of thousands - ultimately millions — of African slaves. There is limited demographic data for the pre-census era, unfortunately, particularly for these two groups.

I compile existing data on the racial makeup of Portuguese-occupied areas in South America for ten periods, from shortly after settlement until the end of the international slave trade, and supplement them with new Native and African headcount estimates based on: (1) commodity output (sugar, gold and coffee) and productivity; (2) aboriginal population densities in colonised areas; and (3) trans-Atlantic slave voyages and imputed imports. My consolidated figures elucidate demographic trends, including the transition from a majority of Native descent into one of predominantly African ancestry by the mid- $18^{\text {th }}$ century.

The demographic and economic histories of Brazil are intimately related because of its reliance on forced labour: shifts in racial composition traced the geography of staple production, a connection I explore in related work. Race is important, not because of any innate differences between people, but because society continues to be affected by the legacy of slavery. 


\section{REFERENCES}

Alden, D. (1963): «The Population of Brazil in the Late 18th Century: A Preliminary Study». Hispanic American Historical Review 43 (2), pp. 173-205.

Alden, D. (1984): "Late Colonial Brazil, 1750-1808», in L. Bethell (ed.), The Cambridge History of Latin America. Cambridge: Cambridge University Press, vol. 2, pp. 601-660.

Alesina, A., and La Ferrara, E. (2005): «Ethnic Diversity and Economic Performance». Journal of Economic Literature 43 (3), pp. 762-800.

Anchieta, J. (1933 [1585]): Cartas, Informações, Fragmentos Historicos e Sermões. Rio de Janeiro: Civilização Brasileira.

Antonil, alias Andreoni J. A. (1923 [1711]): Cultura e Opuléncia do Brasil, 4th edition. São Paulo: E. Taunay.

Bergad, L. W. (2007): The Comparative Histories of Slavery in Brazil, Cuba, and the United States. New York: Cambridge University Press.

Berredo, B., and Pereira de (1989 [1718]): Anais históricos do estado do Maranhaõ. Iquitos, Perú: CETA.

Bethell, L. (1970): The Abolition of the Brazilian Slave Trade: Britain, Brazil and the Slave Trade Question, 1807-1869. Cambridge: Cambridge University Press.

Bethell, L., and Carvalho, J. M. (1989): «1822-1850», in L. Bethell (ed.), Brazil: Empire and Republic, 1822-1930. Cambridge: Cambridge University Press, pp. 45-112.

Blume, H. (1985): Geography of Sugar Cane: Environmental, Structural, and Economical Aspects of Sugarcane Production. Berlin: Verlag Dr. Albert Bartens.

Boxer, C. R. (1962): The Golden Age of Brazil. Berkeley: University of California Press.

BRITo, D. A. (1592): Sumario e descripção do reino de Angola, e do descobrimento da ilha de Loanda e da grãdeza das capitanias de estado do Brasil. Lisbon: Biblioteca Nacional.

Burlamaqui, F. L. C. (1862): Monographia da canna d'assucar. Rio de Janeiro: N. L. Vianna e filhos.

Cadena Vilhasanti, P. (1963 [1629]: «Descripción de la provincia del Brasil», in F. Mauro (ed.), Le Brésil au XVIIe siècle: Documents inédits relatifs à l'Atlantique portugais. Coimbra.

CARDIM, F. (1847 [1583]): Narrativa Epístolar de uma Viagem e Missão Jesuítica. Lisbon: Imprensa Nacional.

Cardoso, Gerald. (1983): Negro Slavery in the Sugar Plantations of Veracruz and Pernambuco, 1550-1680: A Comparative Study. Washington, DC: University Press of America.

CIA (2012) «World Factbook, Brazil». Available at www.cia.gov/library/publications/ the-world-factbook/geos/br.html (accessed 1 April 2012).

ConRaD, R. E. (1986): World of Sorrow: The African Slave Trade to Brazil. Baton Rouge: Louisiana State University Press.

Cunha, M. C. (1992): "Introdução a uma História Indígena», in M. C. Cunha (ed.), Hístoria dos Índios no Brasil. São Paulo: Companhia das Letras, pp. 9-24.

Curtin, P. D. (1969): The Atlantic Slave Trade: A Census. Madison: University of Wisconsin Press.

Eltis, D. (2001): "The Volume and Structure of the Transatlantic Slave Trade: A Reassessment». William and Mary Quarterly 58 (1), pp. 17-46.

Eltis, D., Behrendt, S., Richardson, D., and Klein, H. (1999): The Trans-Atlantic Slave Trade. Cambridge: Cambridge University Press, CD-ROM.

Filho, O. B. (1952): A Fazenda do Café em São Paulo. Rio de Janeiro: Ministério da Agricultura. 
Freyre, F. B. (1977 [1675]): Historia da Guerra Brasilica. Recife: Governo de Pernambuco.

Gândavo, P. M. (1965 [1576]): Tratado da Província do Brasil. Rio de Janeiro: Instituto Nacional do Livro.

Goulart, M. (1975): Escravidão Africana no Brasil: Das Origens À Extinção do Tráfico, 2nd edition. São Paulo: Editora Alfa-Omega.

GutiérReZ, H. (1987): «Demografia escrava numa economia não-exportadora: Paraná, 1800-1830». Estudos Econômicos 17 (2), pp. 297-317.

Hemming, J. (1978): Red Gold: The Conquest of the Brazilian Indians, 1500-1760. Cambridge: Harvard University Press.

Hemming, J. (1987): «Indians and the Frontier», in L. Bethell (ed.), Colonial Brazil. Cambridge: Cambridge University Press, pp. 145-189.

Instituto Brasileiro de Geografia e Estadística (IBGE). Séries Estatísticas \& Séries Históricas. Instituto Brasileiro de Geografia e Estadística. Available at www.ibge. gov.br/series_estatisticas (accessed 1 June 2010).

Johnson, H. B. (1987): «Portuguese Settlement, 1500-1580», in L. Bethell (ed.), Colonial Brazil. Cambridge: Cambridge University Press, pp. 1-38.

KLeIn, H. S. (2010): The Atlantic Slave Trade. Cambridge: Cambridge University Press.

KLEIN, H. S., and LunA, F. V. (2004): «Slave Economy and Society in Minas Gerais and São Paulo, Brazil in 1830». Journal of Latin American Studies 36 (1), pp. 1-28.

KLeIN, H. S., and Luna, F. V. (2010): Slavery in Brazil. New York: Cambridge University Press.

LeIte, S. (1938): Suma histórica da Companhia de Jesus no Brasil (assistência de Portugal) 1549-1760. Lisbon: Junta de Investigaçoẽs do Ultramar.

LibBy, D. C., and Paiva, C. A. (2000): «Alforrias e forros em uma freguesia mineira: São José d'El Rey em 1795». Revista Brasileira de Estudos de População 17 (1/2), pp. 17-46.

Livi-Bacci, M. (1992): A Concise History of World Population. Cambridge: Blackwell.

Livi-Bacci, M. (2001): «500 Anni di Demografia Brasiliana: Una Rassegna». Popolazione e Storia (1), pp. 13-34.

LunA, F. V. (1980). "Minas Gerais: Escravos e Senhores - Análise da Estrutura Populacional e Econômica de Alguns Centros Mineratórios (1718-1804)». São Paulo: Departamento de Economia, Universidade de São Paulo, PhD Thesis.

Marchant, A. (1942): From Barter to Slavery: The Economic Relations of Portuguese and Indians in the Settlement of Brazil 1500-1580. Baltimore: John Hopkins University Press.

Marcílio, M. L. (1984): "The Population of Colonial Brazil», in L. Bethell (ed.), The Cambridge History of Latin America. Cambridge: Cambridge University Press, vol. 2, pp. 37-66.

Martins Filho, A., and Martins, R. B. (1983): "Slavery in a Nonexport Economy: Nineteenth-Century Minas Gerais Revisited». Hispanic American Historical Review 63 (3), pp. 537-568.

Mauro, F. (2000): «La Expansión Europea desde los Orígenes hasta Finales del Siglo XV», in UNESCO (ed.), Historia General de América Latina. París: UNESCO, vol. 2, pp. 49-70.

McEvedy, C., and Jones, R. (1978): Atlas of World Population History. Middlesex: Penguin Books.

Mello, P. C. (1977). «The Economics of Labor in Brazilian Coffee Plantations, 18501888». Chicago: Department of Economics, University of Chicago, PhD Thesis.

Merrick, T. W., and Graham, D. H. (1979): Population and Economic Development in Brazil: 1800 to the Present. Baltimore: Johns Hopkins University Press. 
Metcalf, A. C. (1992): Family and the Frontier in Colonial Brazil. Berkeley: University of California Press.

Monteiro, J. M. (1994): Negros da Terra: Índios e Bandeirantes nas Origens de São Paulo. São Paulo: Companhia das Letras.

Moreno, D. C. (1955 [1612]): Livro que Dá Rezão do Estado do Brasil. Recife: Arquivo Publico Estadual.

MоттA, J. F. (2006): «Escravos daqui, dali e de mais além: o tráfico interno de cativos em Constituição (Piracicaba), 1861-1880». Revista Brasileira de História 26 (52), pp. 15-47.

Newson, L. A. (2006): «The Demographic Impact of Colonization», in V. BulmerThomas, J. H. Coatsworth, and R. Cortés Conde (eds.), Cambridge Economic History of Latin America. New York: Cambridge University Press, vol. 1, pp. 143-184.

Perrone-Moisés, B. (1992): «Índios Livres e Índios Escravos: Os Princípios da Legislação Indigenista do Período Colonial (Séculos XVI a XVIII)», in M. C. Cunha (ed.), Hístoria dos Índios no Brasil. São Paulo: Companhia das Letras, pp. 115-132.

Petrone, P. (1995): Aldeamentos Paulistas. São Paulo: Editora da Universidade de São Paulo.

Roosevelt, A. C. (1992): «Arqueologia Amazônica», in M. C. Cunha (ed.), Hístoria dos Índios no Brasil. São Paulo: Companhia das Letras, pp. 53-86.

Rosenblat, A. (1954): La Población Indígena y el Mestizaje en América. Buenos Aires: Editorial Nova.

Russell-Wood, A. J. R. (1987): «The Gold Cycle, c. 1690-1750», in L. Bethell (ed.), Colonial Brazil. Cambridge: Cambridge University Press, pp. 190-243.

Sánchez-Albornoz, N. (1974): The Population of Latin America: A History. Berkeley: University of California Press.

Schwartz, S. B. (1974): "The Manumission of Slaves in Colonial Brazil: Bahia, 1684-1745». Hispanic American Historical Review 54 (4), pp. 603-635.

Schwartz, S. B. (1985): Sugar Plantations in the Formation of Brazilian Society. New York: Cambridge University Press.

Schwartz, S. B. (1987): «Plantations and Peripheries, c. 1580 - c. 1750», in L. Bethell (ed.), Colonial Brazil. Cambridge: Cambridge University Press, pp. 67-144.

Simonsen, R. C. (1937): História Econômica do Brasil 1500-1820. São Paulo: Companhia Editora Nacional.

SLENES, R. (1975): «The Demography and Economics of Brazilian Slavery: 1850-1888». Palo Alto: Department of History, Stanford University, PhD Thesis.

SoARes, S. F. (1860): Notas Estatísticas sobre a Produção Agrícola e Carestia dos Géneros Alimentícios no Império do Brazil. Rio de Janeiro: J. Villeneuve e Companhia.

Soares de Sousa, G. (1851 [1587]): Tratado Descritivo do Brasil em 1587. Rio de Janeiro: Typographia Universal de Laemmert.

Souza, M. A. G. (2000): O Descobrimento e a Colonização Portuguesa no Brasil. Belo Horizonte: Editora Itatiaia.

Stein, S. J. (1985): Vassouras. Princeton: Princeton University Press.

Steward, J. H. (1946): Handbook of South American Indians. Washington: Government Printing Office.

Trans-Atlantic Slave Trade Database (2010): This is an online searchable database, which can be cited as follows: Trans-Atlantic Slave Trade Database. Emory University. http://slavevoyages.org (accessed 1 August 2010).

Varnhagen, F. A. (1956): História Geral do Brasil, 5th edition. São Paulo: Edições Melhoramentos.

VIERA, A. (1943 [1660]): «Regulamento das Aldeias (Visita)», in S. Leite (ed.), História da Companhia de Jesus no Brasil. Rio de Janeiro: Editora Nacional do Livro. 